\title{
TEACHING CULTURAL STUDIES AND AREA STUDIES IN THAILAND
}

\author{
Michael Hayes ${ }^{1}$
}

\begin{abstract}
This short paper discusses teaching western Cultural Studies, in particular Australian Cultural Studies, in Thailand. By contextualising pedagogical issues, such as classroom practices and course contents, with the surrounding economic, institutional, and national educational agendas, this paper outlines some of the tensions between western and Asian tertiary education systems. Specifically, examining the development and place of cultural studies in the western university highlights the inability for cultural studies to articulate its specific view of culture.
\end{abstract}

This paper discusses some aspects of teaching western Cultural Studies, in particular Australian Cultural Studies, in Thailand, and illustrates the issues raised with examples from my own teaching. Fundamentally, this paper is intended to address the purposes, the desired outcomes, and the ethical and/or economic results of western Cultural Studies in Thailand. To get ahead of myself a little here, I want to polemically suggest that Thailand does not need Cultural Studies as it is taught in the west, but rather can produce its own Cultural Studies however, one with multiple relations to

\footnotetext{
${ }^{1}$ Lecturer, Australian Studies Centre Kasetsart University
}

western Cultural Studies, one linked to the genealogy of British, US, and Australian Cultural Studies, and one that is grounded in Thai critical analysis, university practice, and cultural understandings. While this is an obvious response - after all Thai students, academics, and universities are different from western universities, these kinds of cultural specificities are rarely addressed in accounts of the curriculum development, or the theoretical engagement of nonwestern Cultural Studies. This short paper attempts to read across features of Cultural Study curriculums, classroom practices, contemporary theories, and institutional powers to suggest some relationships that Cultural Studies can have with Thai university education. As such, it is a mix of theory, anecdote, practice, complaint and praise; also it is aimed more at the western academic grounded in teaching Cultural Studies in the west, for Thai academics know better than me the problems and solutions of integrating and contrasting western and Thai systems.

Firstly, I want to define the terms and disciplines examined in the paper. I use 'western' to describe Cultural Studies because, as I will argue, the discipline of Cultural Studies taught in the west is 
strictly located within western ideas, western teaching practices and research, and western institutions. That the term 'west' conflates the many different sorts of Cultural Studies is not a concern for me here - I am not analysing the distinctions within Cultural Studies, but the distinctions between university disciplines in western universities and Southeast Asian universities.

Very briefly, western Cultural Studies, which emerged from England with the Centre for Contemporary Cultural Studies (CCCS) in Birmingham, and was later exported predominantly to the US and Commonwealth countries, is most often associated with literature departments but is a rather heterogeneous discipline which vigorously proclaims its interdisciplinary nature, its emphasis on critical analysis, and its broaching of political and social issues within the university. Cultural Studies is not, however, independent from these institutions; it exists within a matrix of university pedagogy and a canon of texts (such as those by Raymond Williams, Hebdidge, Spivak, de Certeau, and Bourdieu). Further, it concentrates on investigating textual issues (such as film, literature, and media studies), and issues of gender, ethnicity, race and class. Thus I would not describe Cultural Studies as Lawrence Grossberg chooses, as

At every moment, every practice of Cultural Studies is something of a hybrid, with multiple influences. Every position in Cultural Studies is an ongoing trajectory across different theoretical and political projects. $^{2}$

${ }^{2}$ Grossberg (1995: 17)
Firstly, this generalisation sums up every university discipline. Secondly, it does not acknowledge that relationships of power, validations of authority, or canonisation of texts and authors are an implicit part of the discipline. I prefer Stuart Hall's take on the subject. He says:

Now, does it follow that Cultural Studies is not a policed disciplinary area?... I am not happy with that formulation. Although Cultural Studies as a project is open ended, it can be simply purist in that way.... [I]t does have some will to connect; it does have some stake in the choices it makes. ${ }^{3}$

Obviously there are pressures in Cultural Studies, both on a disciplinary and political level, about what is considered legitimate Cultural Studies, and as Hall emphasises, the chosen projects and the multiple connections establish an area in which the discipline moves. Finally, and most importantly, Cultural Studies as I define it here is strictly a western discipline, but one that has at points been appropriated by non-western academies (notable examples include Cultural Studies in Taiwan and Hong Kong). This is not meant to glorify the discipline as a signifier of the 'progress' of western education; rather its west-ness is a significant handicap and one that if not seriously addressed and prefaced in Cultural Studies work, can significantly limit its critical aspirations.

There is a failure to address the ability of theory and practice to travel outside their western frame. Even in Gayatri Spivak's more recent work where she directly

${ }^{3}$ Hall (1996: 263) 
addresses Cultural Studies, marginality, and academic practice, the academy is always unquestionably situated in the west. Her "Marginality in the Teaching Machine"s proposes a binary between the university and the "revolutionary practices" which assumes the university will always be situated in the west, opposed to the 'revolutionary' east. I admit this is somewhat of a generalisation and simplification of a far more sophisticated argument in which she explicitly positions her work in the west; but it is always left to stand that the curriculum and academy we talk about are western. Perhaps only in Rey Chow's work which examines the relationship between mainland Chinese academics and nonresident Chinese academics do we see a (western) critic moving towards addressing this tension. ${ }^{5}$

This paper also covers the topic of area studies, a term used to note studies of a specific region or country, such as Australian Studies or South East Asian Studies. Research and teaching in area studies seeks to cross disciplinary borders to bring together information from a wide variety of sources on the region, so that, for instance, Australian Studies combines specific studies in geography, economics, politics, history and so on. When I speak of area studies here, I refer to the Cultural Studies aspects of area studies, or how to discuss a region's culture as a topic of knowledge. Area studies, in particular Australian Studies, appears grounded in ideas of nationalism - whether nationalism is supported or criticised, it features as a motivating concern, one that I shall return to.

\footnotetext{
${ }^{4}$ Spivak (1993)

${ }^{5}$ Chow (1993)
}

Within these two disciplines I wish to locate my position, and the politics surrounding the teaching of Australian Studies and Cultural Studies in Thailand. It would be pleasant, but totally naive, to suggest that delivering Cultural Studies in Thailand is an apolitical gesture which merely seeks to broaden the educational horizon of Thai students by the help of the Australian university sector. Firstly, there are obvious locations from which I speak (as a male white Australian) which determine a politics and a privilege. But also the discipline of Australian Studies is delivered alongside the unarticulated but clearly important economy of recruiting international students to study in Australia. A highly competitive and lucrative market, some estimates have suggested that $20 \%$ of some Australian university budgets, and a total of AUD $\$ 3$ billion, comes from foreign fee-paying students - and these are predominantly Southeast Asian. Recruitment cannot operate without a university presence in Thailand, so research links and academic exchanges legitimise this most important economic component of Australian universities. I may also point out that this market is competitive between the US, British, New Zealand, continental, and Canadian universities. As much as we like to think that these market forces do not play a part in the Humanities, there are most clearly economic factors at work (alongside ethical, institutional and pedagogical factors) which determine what gets taught by whom.

Putting Australia into the minds of undergraduate students through area studies programs may later influence their choice of country for post graduate education - most definitely not one of my 
intentions but certainly a factor in the Australian government's decision to fund such courses. Thus Australian Studies (and by association Cultural Studies) may be claimed to be one pedagogical aspect of a huge recruitment industry worth billions. This does run in contradistinction to the position of Cultural Studies within the academy as not professional or career orientated but research and education based. While seemingly commercially nonviable, there are possibly long term benefits of supporting such programs.

I point this out because I think it important that some of the politics of why we teach western subjects in non-western countries needs to be articulated. This does not undermine the ability of Australian Cultural Studies to perform and does not weaken the academic authority of the various courses - for they are not determined by the economic drives of this market alone; however, they are made possible by this market. Also, these kinds of economic contexts detail some pressures that Australian Cultural Studies will face from various agencies - those who wish the discipline to be conducive to recruitment alongside the discipline's critical and theoretical issues. There are many confrontations at this point: between the west-ness of Australian Cultural Studies and the east-ness of Thai universities where a balance must be made between providing a western course that demonstrates the practice of western education in the classroom, and providing a course that needs to be responsive to the institutional environment and student population's unfamiliarity with western teaching models; also between analysing a culture so students understand and will want to study in it, and criticising a culture using contemporary theories of gender, race and class. Finally, there are the pressures with the wealthy western universities who have greater access to resources, academics, and funding, that can ultimately use this authority to determine curriculum activity.

At this point I want to explain some of these complexities with an anecdote that says something of being a westerner teaching a western subject in Thailand. It comes in the form of a question asked to me by a student at the end of a class. In this class I was talking about the Pauline Hanson affair which had wide newspaper coverage in Bangkok and at that time was putting Australia on the front page of the English language papers almost daily. While the class was about multiculturalism and cultural diversity, it also detailed something of Australia's rather depressing history of racism (its nineteenth century fear of Asian invasion, the white Australia policy, and the continued racism against Aboriginal communities), at the same time addressing racism's recent resurgence under Prime Minister John Howard, who has done much to make Hanson's politics possible. At the end of the class, the question the student asked was "Why is Australia such a racist country?"

There are a couple of remarkable things about this question. Firstly that a student asked a question in the first place. In an educational system where questions can sometimes be interpreted as a questioning of the teacher's knowledge, and also among a general student population who are often unwilling to ask questions, to have such a question was a welcome surprise, but the subject of the question was not. The student would have seen this as a legitimate question because it was already apparently 
agreeing with my knowledge - after all I had just detailed a history of racism to the class. $^{6}$

The class and the students' response demonstrates the fundamental basis of much of Cultural Studies in the west. This question forced me to think about the kind of picture I am giving of Australia: is this appropriate for this class and how does this go against the promotion of Australian culture? At once this brings into focus the strategies of a course such as Australian Studies which at some level displays a certain nationalism and operates within the above mentioned economy. In light of the economic undercurrent of the course, it does seem appropriate to promote Australia as a tolerant, multicultural country which we wish it to be. However, should only this aspect be taught and any mention of racism be avoided or erased? There certainly are problems with airing Australia's dirty laundry internationally, but it would be, I consider, academically duplicitous to erase these issues from the curriculum.

The structure of the course was demonstrating the western specificity of the teaching practice of Cultural Studies itself. It is not quite accurate that disciplines of the humanities in Southeast Asia, as some people contend, are generally taught as facts, much like the sciences. Yet, the Humanities in Southeast Asia are also not disciplines where personal opinion, individual ideas, and unorthodox thinking are rewarded and valorised as they are in

\footnotetext{
${ }^{6}$ There are many reasons for the unwillingness to ask questions. Primarily, as I will detail, questions are a western pedagogical practice. Other issues include language, not wanting to criticise, and perhaps shyness as well.
}

the west. The western tendency towards a humanities which privileges individualism and opinion has part of its emergence in the Humanism and Romanticism of $18^{\text {th }}$ century Europe, particularly in the development of the universities at this time. I want to pick up on this apparent tangent for a while and discuss some interesting points made in a recent paper on the genealogy of the critical humanities by Ian Hunter. In this paper, "The Critical Disposition: Some Historical Configurations of the Humanities," Hunter details the development of the critical humanities particularly in early modern Germany. In his detailed discussion of the forces involved in the formation of the humanities at university, Hunter details connections between humanism, moralism, and the confession, or how the university is closely associated to the church. ${ }^{7}$ A properly trained civil servant at this time was someone who had undertaken a humanities course and could demonstrate the "linguistic skills and ethical disposition required for participation in the public life of the city." In Hunter's study, Lutherism, which involved confessional practice, was an able model for the development of linguistic skills and ethical disposition. The public confession, which Foucault has analysed at length in his The History of Sexuality: An Introduction, is a means to develop relationships of power through producing information from the person confessing which is in turn used by the

\footnotetext{
${ }^{7}$ Hunter (1997: 33); Young (1995). Thai education is closely linked to Buddhism, as primary school initially (and in many cases still) operate in Buddhist temples.

${ }^{8}$ See also Robert Young, (1995) for an analysis of the development of the university, the categorisation of culture, and the institutionalisation of the Humanities.
} 
authoritative listener. Since, part of humanism seems to be confessional, this practice of self-criticism, which is most obvious in detailing a history of racist Australia to Thai students, is a strictly western practice. Airing dirty laundry in public is not a Southeast Asian practice and to the students demonstrates weakness, not strength. But confession is only one of the ways in which discussing Australian racism locates Cultural Studies as distinctly western, for the class was based on certain assumptions of criticism that are distinct to the west.

A working paper by the Asia-Australia Institute at UNSW, titled "Perceiving Education," pertinently outlines some of these distinctions between student practice of Thai and western students. I will take the liberty to quote this section at length because it succinctly catalogues those differences faced by western teachers, and indicates what kind of classroom practice occurs in Thailand:

Japanese, Indonesian, Thai and Chinese [students] are confused by the Australian education system.... [T] hey are uniformly confronted [by] their lists of possible readings, choices of assignments and vague outlines of study, apparently open to change by the subjective whims of fellow students. Teachers, often untidily and even poorly dressed, seem to Southeast Asian students to have done little preparation for their class and rely on the students to keep things going. When a student makes an error, the teacher points it out, pushing the student to reveal the extent of his or her ignorance. Teachers also withhold their superior store of knowledge, forcing the students to find for themselves knowledge the teachers almost certainly already have at their disposal. Even when this has been done, there is no praise. Copying expert knowledge, far from showing the student has discovered an authoritative and treasured source, is frowned upon, even labelled 'plagiarism.' Instead, the learner must pose as master and produce 'original' work. Meticulous script and delicacy of phrasing, ... laboriously copied perfectly by hand in its final draft, are often ignored or rejected as being preoccupied with neatness.

A subject such as Cultural Studies, based on ideas of criticism, is thus problematic to the Thai student. Curriculum structure and class practice of Cultural Studies students in the west are based on seminar-style discussion, part Socratic dialogue and part reliant on the western myth of the individual; a myth supporting the value of 'original' work and 'self discovery.' To return once again to Ian Hunter, to be 'critical' in pre-modern Germany was "based on the sceptical suspension of positive knowledge and reflexive recovery of its metaphysical conditions." 10 That is, while being critical necessitates activating a disbelief, the corollary action is the movement towards an already discovered universal truth. I may make a gross generalisation and suggest that Southeast Asian universities have merely cut out the 'sceptical suspension' and moved quickly onto the truth, while western universities often like to consider they provide freedom

\footnotetext{
${ }^{9}$ Milner (1994: 33)

${ }^{10}$ Hunter (1997: 47)
} 
and individuality during this period of suspension before marshalling the students back to the truth. The emergence of the humanities clearly outlines the cultural specificity of humanist discourses in Western universities - for we must remember that for most of the previous two centuries the 'humans' of the humanist movement where white males. And the 'human' of the humanities is a singular, individual being and not the more shared, familial identity which is closer to structures of identity in Southeast Asian countries.

Finally, these details of classroom practice emphasise the most fundamental difference in Cultural Studies: the concept of culture is something quite different in Australia and Thailand. In Australia there is constantly a questioning of what it means to be Australian - for there are questions of Aboriginal sovereignty, ownership of the land, multiculturalism, all of which propose Australia is many cultured; yet underneath all this is the undeniable fact that national identity, economic wealth, and cultural activity is controlled, perhaps monopolised, by Anglo-Celtic Australians. This leads me to comment on one of my numerous spectacular failures in class: I attempted to engage students in the dialogue of nationalism and national identity by explaining the concept of an invented tradition, of nationalism as a hegemonic force (using examples by writers such as Eric Hobsbawn, Benedict Anderson, Richard White, Sulak Sivaraksa, and Thongchai Winichukul). I wanted the students to question what made them Thai. Try as I might, there was no question to the students about their nationalism, and more importantly no need for them to question their nationality. Their culture, their history, their monarchy, their religion, and their hair colour, to them, all emphasised undeniably their Thai-ness. They were Thai and any questioning was just the poor farang (white) teacher making up spurious assumptions. And for these reasons the students could not understand (but were interested in) the preoccupation Australians have with the meaning of being Australian. Quite clearly what are issues and concerns of one nation are not the same for another. This may appear to make invalid the principle of Australian Cultural Studies, yet it also shows the value of such studies to locate through discerning its difference to other nations the issues and tensions of a culture.

Now the question is not whether Thailand (or for that matter any other Southeast Asia country) needs to include western Cultural Studies in its curriculum. Arguments about utility often get reduced to simplistic economic equations or humanistic imperatives. The real issue is how can one teach from a western background in Thailand and actively educate the students, engage them in important issues, and introduce critical concepts which will help them understand both the west and their own country. And how can this be done so that it is simultaneously relevant to Thailand's and Australia's educational system? This challenge, I consider, is not part of the apparent 'globalisation' of education - for the rhetoric of globalism is an attempt to mask some of the fundamental myths of western style education (such as humanism's premise on individuality and confessions) and imply the western university holds and dispenses all knowledge. There is little point in 'westernising' Southeast Asian institutions and making them irrelevant to their own non-western populations; however, there 
is value in introducing these concepts as objects of study in themselves. It is undeniable that movement between western and eastern education has increased dramatically, and it is a matter of ensuring these relationships are not based on patronising or universalist assumptions of knowledge.

\section{References}

Chow, R. 1993. Writing Diaspora: Tactics of Intervention in Contemporary Cultural Studies. Bloomington: Indiana UP.

Foucault, M. 1987. The History of Sexuality: An Introduction. Trans. Robert Hurley. Harmondsworth: Penguin.

Grossberg, L. 1995. We Gotta Get Out of this Place. London: Routledge.

Hall, S. 1996. Cultural Studies and its Theoretical Legacies. In Stuart Hall: Critical Dialogues in Cultural Studies, ed. by David Morley and Kuan Hsing Chen, pp. 262-275. London: Routledge.

Hunter, I. 1997. The Critical Disposition: Some Historical Configurations of the Humanities. UTS Review 3.1: 271-89.

Milner, A. ed. 1994. Perceiving 'Education'. Australian-Asian Perceptions Project, Sydney: Asia Australia Institute.

Spivak, G. 1993. Marginality in the Teaching Machine. In Spivak, Outside in the Teaching Machine, pp. 53-76. London: Routledge. 